\title{
Spectral analyses of fresh and dry Hypericum perforatum L. Effects with colloidal nano silver 30 ppm
}

\author{
Ignat Ignatov ${ }^{{ }^{*}}$, Teodora P. Popova ${ }^{2}$, Ralitsa Bankova ${ }^{3}$ \& Nikolai Neshev ${ }^{4}$ \\ ${ }^{1}$ Scientific Research Center of Medical Biophysics (SRCMB), Sofia 1111, Bulgaria \\ ${ }^{2}$ Department of Infectious Pathology, Hygiene, Technology and Control of Food of Animal Origin, Faculty of Veterinary Medicine, University of Forestry, \\ $10 \mathrm{Kl}$. Ohridski Blvd., Sofia 1756, Bulgaria \\ ${ }^{3}$ Department of Internal Noncommunicable Diseases, Pathhology and Pharmacology, Faculty of Veterinary Medicine, University of Forestry, 10 KI. \\ Ohridski Blvd., Sofia 1756, Bulgaria \\ ${ }^{4}$ Faculty of Physics, Sofia University "St. Kliment Ohridski", Sofia 1000, Bulgaria \\ *Email: mbioph@abv.bg
}

\section{OPEN ACCESS}

\section{ARTICLE HISTORY}

Received: 25 September 2021

Accepted: 21 November 2021

Available online

Version 1.0: 01 January 2022

\section{Check for updates}

\section{Additional information}

Peer review: Publisher thanks Sectional Editor and the other anonymous reviewers for their contribution to the peer review of this work.

Reprints \& permissions information is available at https://horizonepublishing.com/ journals/index.php/PST/open_access_policy

Publisher's Note: Horizon e-Publishing Group remains neutral with regard to jurisdictional claims in published maps and institutional affiliations.

Indexing: Plant Science Today, published by Horizon e-Publishing Group, is covered by Scopus, Web of Science, BIOSIS Previews, Clarivate Analytics, etc. See https:// horizonepublishing.com/journals/index.php/ PST/indexing_abstracting

Copyright: () The Author(s). This is an openaccess article distributed under the terms of the Creative Commons Attribution License, which permits unrestricted use, distribution and reproduction in any medium, provided the original author and source are credited (https://creativecommons.org/licenses/ by/4.0/)

\section{CITE THIS ARTICLE}

Ignatov I, Popova T P, Bankova R, Neshev N. Spectral analyses of fresh and dry Hypericum perforatum $\mathrm{L}$. Effects with colloidal nano silver 30 ppm . Plant Science Today. 2022;9(1):4147. https://doi.org/10.14719/pst.1429

\begin{abstract}
Spectral analyses of $1 \%$ water extracts of fresh and dry Hypericum perforatum L. and $1 \%$ dry H. perforatum with colloidal nano silver (NSPs) $30 \mathrm{ppm}$ were conducted. The nano silver is standardised and patented by the Swiss company Evodrop. Non-equliblrium energy spectrum (NES) and Differential non-equliblrium energy spectrum (DNES) methods were used for the spectral analysis. A comparative analysis of $1 \%$ extracts of fresh and dry H. perforatum was performed in order to determine the local extremums for effects of nerve tissue conductivity at $(-0.1112) \mathrm{eV}$, anti-inflammatory $(-0.1212) \mathrm{eV}$, anti-tumor effects $(-0.1387) \mathrm{eV}$. The results showed stimulating effect on the nervous system and improvement of nerve conduction (local extremums $E=$ $-0.1112 \mathrm{eV})(\lambda=11.15 \mu \mathrm{m})\left(\tilde{\mathrm{v}}=897 \mathrm{~cm}^{-1}\right)$, as well as anti-inflammatory effect $(E$ $=-0.1212 \mathrm{eV})(\lambda=10.23 \mu \mathrm{m})\left(\tilde{v}=978 \mathrm{~cm}^{-1}\right)$ and inhibition of development of tumor cells at a molecular level $(E=-0.1387 \mathrm{eV})(\lambda=8.95 \mu \mathrm{m})\left(\tilde{v}=1117 \mathrm{~cm}^{-1}\right)$. It was found that clusters of 16 and 15 water molecules are formed in the water herbal extracts of fresh $\mathrm{H}$. perforatum and of dry $\mathrm{H}$. perforatum with AgNPs $30 \mathrm{ppm}$. The fresh plant showed better results then the dry one. The addition of colloidal nano silver $30 \mathrm{ppm}$ led to better results of the drug.
\end{abstract}

\section{Keywords}

Hypericum perforatum, colloidal nano silver, anti-inflammatory action, NES, DNES

\section{Introduction}

The application of herbs by doctors and pharmacists is a widespread practice worldwide, including in Bulgaria, which is also a part of the national culture. Nowadays, in our country It is regulated by the Act of Health of 2005. In recent decades, foreign plants and products thereof have also been used more and more frequently.

Hypericum perforatum L. (St. John's wort), is a herbaceous perennial plant which grows in Europe, West Asia and North Africa. This herb is also grown in South Africa, Australia, New Zealand, India and South America and it is used as a medicinal plant there. In Bulgaria, it grows all over the country in the lowlands - on grassy places and along roads (1). In our folk medicine, St. John's wort is among the most commonly used herb. It is applied mainly as a means of treating a number of gastrointestinal diseases (gastric and duodenal ulcers with hyperacidity, acute and chronic gastritis, enterocolitis, indigestion, diarrhea, stomatitis, periodontitis, gingivitis, pharyngitis, etc.) (2). The 
herb has a healing effect on wounds and is used at contaminated purulent and slow-healing wounds on the skin and mucous membranes, cuts, abrasions and burns. The flavonoids in the herb give it a capillarotonizing effect, so it is applied in diseases accompanied by bleeding, inflammation, swelling and more. such as hemorrhoids, heavy menstruation, rheumatism, inflammation of the bladder, colitis and others. The herb has a sedative effect and is also useful in patients with depression and neurological suffering $(2,3)$. The aboveground parts of $H$. perforatum (leaves, stem and flowers) are used, which are picked during flowering known as Hyperici herba. The products containing St. John's wort are in the form of tablets, capsules, teas, tinctures, alcohol and oil extracts.

St. John's wort is among the most studied medicative plants worldwide due to its rich chemical content and curative properties. The biologically active substances (BAS) present in it can be classified into several groups as: phloroglucinols; naphtodianthrons; flavonoids, procyanidins, tannins and related substances; simple phenolic compounds (phenylpropanoids and others); xanthones and volatile substances (Table 1 ) as well as essential oil (3,

Table 1. Bioactive compounds present in dried Hyperici herba [3, 4]

\begin{tabular}{|c|c|}
\hline 0 & Compounds \\
\hline Phloroglucinols & Hyperforin; Adhyperforin; Hyperfirin; Adhyperfirin \\
\hline Naphthodianthrones & $\begin{array}{l}\text { Hypericin; Protohypericin; Pseudohypericin; Pro- } \\
\text { topseudohypericin; Cyclopseudohypericin }\end{array}$ \\
\hline & $\begin{array}{l}\text { Quercetin; Quercitrin; Isoquercetrin; Hyperoside; } \\
\text { Rutin; Miquelianin; Guaijaverin; Avicurarin; Astilbin; }\end{array}$ \\
\hline $\begin{array}{l}\text { Flavonoids, procya- } \\
\text { nidins, tannins, and } \\
\text { related compounds }\end{array}$ & $\begin{array}{l}\text { Quercetin; 3-O-(2"-acetyl)- } \beta \text {-dgalactopyranoside; } \\
\text { Kaempferol; Nicotiflorin; I3,II8-Biapigenin; Amentofla- } \\
\text { vone; Amentoflavone; Procyanidin B2; Isoorientin; } \\
\text { Cyanidin 3-O- } \alpha \text {-rhamnoside; Catechin; Epicatechin; } \\
\text { Epigallocatechin }\end{array}$ \\
\hline $\begin{array}{l}\text { Phenylpropanoids and } \\
\text { other simple phenolic } \\
\text { compounds }\end{array}$ & $\begin{array}{l}\text { Neochlorogenic acid; Chlorogenic acid; Chrypto- } \\
\text { chlorogenic acid; Caffeic acid; p-Coumaric acid; 3-O- } \\
\text { (Z)-P-coumaroylquinic } \quad \text { acid; O-(E)-P- } \\
\text { coumaroylquinic acid; p-Hydroxybenzoic acid; Ferulic } \\
\text { acid; Protocatechuic acid; Vanillic acid }\end{array}$ \\
\hline Xanthones & Mangiferin, 1,3,6,7-Tetrahydroxyxanthone \\
\hline Volatile compounds & $\begin{array}{l}\text { Spathulenol; Caryophyllene oxide; } \\
\text { Caryophyllene; } \quad \text { 1-Tetradecanol; } \\
\text { Dodecanol; } \gamma \text {-Muurolene; } \beta \text {-Funebrene;1- }\end{array}$ \\
\hline
\end{tabular}

4).

The main compound answerable for the antidepressant effect of $H$. perforatum is hyperforin (5). It also has anti-inflammatory, antibacterial, anti-tumor and anti-angiogenic effects. An anticlastogenic effect of hyperforin on the indirect mutagen benzopyrene has also been observed (5). Hypericin exhibits antibacterial, antiviral and anti-inflammatory activity (6). It is reported to have antidepressant properties. Other minor ingredients are protohypericin, pseudohypericin (with anti-inflammatory properties), protopseudohypericin and cyclopseudohypericin. These compounds also have antiretroviral and cytotoxic properties (3). Flavonoids, bioflavonoids, anthocyanidins and catechins are the main phenolic compounds (2-4\%), contained in $\mathrm{H}$. perforatum. They have been shown to manifest antioxidant effect, the ability to remove free radicals have cardio- protective, antidiabetic, anti-inflammatory, antiallergic, anti-cancer and potential antiviral effects (7). Procyanidins exhibit antioxidant, antiviral, antimicrobial and vasoactive properties (8). The ethereal oil (0.07$0.25 \%$ ) of dried flowering stems contains mainly the substances $\alpha$-pinene and 2-methyloctane (4).

St. John's wort extracts have a broad spectrum antimicrobial activity against Gram-positive (Staphylococcus aureus, S. mutans) and Gram-negative bacteria (Proteus vulgaris, Escherichia coli, Pseudomonas aeruginosa), as well as yeasts (Candida albicans) (6). Methicillin-resistant and penicillin-resistant S. aureus are particularly susceptible to hyperforin (9). It was reported that hypericin exhibits in vitro antiviral effect against herpes simplex virus-1 (10). Hypericin has been suggested to inactivate coated viruses by altering viral proteins and inhibiting the ability of viruses to fuse with cell membranes (9).

Analyses at $(-0.1212) \mathrm{eV}$ of the effects with mathematical models (11) and Ignatov's, Gluhchev's, Neshev's and Mehandjiev's method for the size of water clusters (12) are performed. The authors reported that at $(-0.1287) \mathrm{eV}$ the size of the water cluster is $0.822 \mathrm{~nm}$. The purpose of the present study was to analyse and compare the results of dry Hypericum perforatum L. with colloidal nano silver and fresh $H$. perforatum by spectral analysis.

\section{Materials and Methods}

Device for Non-equliblrium energy spectrum (NES) and Differential non-equliblrium energy spectrum (DNES) analysis

The apparatus for NES and DNES assays is created by A. Antonov and it is based an optical principle (13). It contains a hermetically closed camera for water drops evaporation at constant temperature $\left(+22-24^{\circ} \mathrm{C}\right)$. The drops of water are set on a transparent waterproof pad, which consists of a glass plate and thin maylar folio. Monochromatic light with filter for yellow color with wave length at = $580 \pm 7 \mathrm{~nm}$ is used. The apparatus measures the angle of evaporation of water drops between $72.3^{\circ}$ and $0^{\circ}$. The DNES was determined in the range between -0.08 and $0.1387 \mathrm{eV}$ or $=8.9-13.8 \mu \mathrm{m}$ by an especially created computer program. The major assessment criterion in the experiments was the average energy $\left(\Delta \mathrm{E}_{\mathrm{H} . . .0}\right)$ of hydrogen $\mathrm{O}$... $\mathrm{H}$-bonds among $\mathrm{H}_{2} \mathrm{O}$ molecules in water specimens. It is measured in $\mathrm{eV}$.

\section{Characteristics of NES and DNES water state spectra}

The $f(\theta)$ function is denoted as spectrum of energy distribution. It is featured by the non-equilibrium procedure of evaporation of water droplets.

The operating tenet of the method for determination of wetting angle of fluid drops on a solid surface, presented by $(13,14)$ was used.

The relation of the energy of hydrogen bonds between water molecules $f(E)$ and $f(\theta$ is expressed as follows: 


$$
f(E)=\frac{14.33 f(\theta)}{\left[1-(1+b E)^{2}\right]^{2}}
$$

In the formula, $b$ depends on the water surface tension, on the number of water molecules at the surface layer of water per unit area, and the initial contact angle of the drop.

The water state spectrum is received from the nonequilibrium process of evaporation of drops of water and, due to that, the term NES is used (16). The evaluated measurement error for $\mathrm{E}$ is $\pm 0.0011 \mathrm{eV}$.

The difference:

$$
E(\theta) E(\theta)_{\text {sample }} E(\theta)_{\text {control sample }}
$$

is denoted as DNES.

DNES is a measurement of the alteration of structure of water as a result of a given impact factor. The combined effect of all other influencing factors except the studied one is the same for the control and the specimen, therefore it is canceled out.

\section{Mathematical models}

Research was conducted of $1 \%$ extracts of the medicinal plant using mathematical models of $(12)$ applied by $(18,19)$.

\section{Colloidal nano silver 30 ppm}

Colloidal silver nanoparticles (AgNPs) at concentrations of $30 \mathrm{ppm}$ were used. It is standardised and patented by the Swiss company Evodrop.

\section{Drugs}

Aboveground parts of Hypericum perforatum L. (leaves, stem and flowers), harvested during flowering were tested. A fresh herb was picked up on the day of the experiment as well as a dried herb were examined. Each of both herb samples (fresh and dried) was soaked in deionized water ( $1 \mathrm{~g}$ herb in 0.100 ( water), as well as in deionized water with AgNPs at final concentrations of $30 \mathrm{ppm}$ (of dry herb) for 24 $\mathrm{hr}$ at room temperature in the same $1 \%$ ratio $(1 \mathrm{~g}$ herb in 0.100 I water with AgNPs). The received water herbal extracts were subjected to spectral analyses.

T-test of Student was applied with 10 measurements to compare the effects of samples of the three experimental groups:

1) $1 \%$ extracts of fresh $H$. perforatum in deionized water (the first group).

2) $1 \%$ extracts of dry $H$. perforatum in deionized water (the second group).

3) $1 \%$ extracts of dry $H$. perforatum with colloidal nano silver $30 \mathrm{ppm}$ in deionized water (the third group).

The control group was deionized water.

\section{Results and Discussion}

Results from spectral analyses with methods NES and DNES

$1 \%$ water extracts of fresh and dry $H$. perforatum, and of dry $H$. perforatum with colloidal nano silver $30 \mathrm{ppm}$ are presented on Table 2 and Fig. 1.
The mean energy $\left(E_{\mathrm{H} . . . \mathrm{O}}\right)$ of hydrogen $\mathrm{H}$...O-bonds between individual $\mathrm{H}_{2} \mathrm{O}$ molecules in NES in $1 \%$ extracts of fresh $H$. perforatum was measured at $E=-0.1243 \mathrm{eV}$. The mean energy $\left(\mathrm{E}_{\mathrm{H}} \ldots \mathrm{O}\right)$ of hydrogen $\mathrm{H}$...O-bonds between individual $\mathrm{H}_{2} \mathrm{O}$ molecules in NES in $1 \%$ extracts of dry $\mathrm{H}$. perforatum was measured at $\mathrm{E}=-0.1210 \mathrm{eV}$. The mean energy $\left(\mathrm{E}_{\mathrm{H...O}}\right)$ of hydrogen $\mathrm{H}$...O-bonds between individual $\mathrm{H}_{2} \mathrm{O}$ molecules in $1 \%$ extracts of dry $\mathrm{H}$. perforatum with colloidal nano silver was determined at $\mathrm{E}=-0.1232 \mathrm{eV}$. The result of control sample with deionized water was $E=-0.1188$ eV.

The results received by DNES method were the next:

For the fresh $H$. perforatum $\mathrm{L} .: \Delta \mathrm{E}=(-0.1243)-(-0.1188)=-$ $0.0055 \pm 0.0003 \mathrm{eV}$

For the dry $H$. perforatum: $\Delta \mathrm{E}=(-0.1210)-(-0.1188)=-$ $0.0022 \pm 0.0001 \mathrm{eV}$.

For the dry $H$. perforatum with colloidal nano silver:

$\Delta \mathrm{E}=(-0.1234)-(-0.1188)=-0.0046 \pm 0.0002 \mathrm{eV}$.

For the three experimental groups the results were at level $\mathrm{P}<0,05$ according to the t-test of Student. These results show a restructuring of $\Delta \mathrm{E}_{\mathrm{H} . . . \mathrm{O}}$ values between individual $\mathrm{H}_{2} \mathrm{O}$ molecules with a statistically significant raise of local extremums in DNES. The local extremums $\left(\mathrm{eV}^{-1}\right)$ were in the function of spreading of energies of hydrogen bonds.

The results of dry $H$. perforatum with colloidal nano silver were higher in comparison with these of dry $\mathrm{H}$. perforatum The difference was $\Delta \mathrm{E}=(-0.0055)-(-0.0046)=(-$ 0.0009) eV.

The alterations of energies of hydrogen bonds of dry $H$. perforatum with colloidal nano silver $30 \mathrm{ppm}$ were closer to energies of hydrogen bonds of fresh $\mathrm{H}$. perforatum.

\section{Mathematical models}

Fresh and dry $H$. perforatum in water and dry $H$. perforatum with colloidal nano silver 30 ppm (12).

The studies of water drops was with the NES method conducted using $1 \%$ extracts of fresh and dry $\mathrm{H}$. perforatum, as well as with dry $H$. perforatum with colloidal nano silver $30 \mathrm{ppm} 1 \%$ in water solution. The mathematical models of $1 \%$ extracts for fresh and dry $\mathrm{H}$. perforatum and dry $\mathrm{H}$. perforatum with colloidal nano silver $30 \mathrm{ppm}$ give important information about the likely number of hydrogen bonds as percent of $\mathrm{H}_{2} \mathrm{O}$ molecules with different values of distribution of energies (Table 2; Fig. 1). These distributions are in connection mainly with the restructuring of $\mathrm{H}_{2} \mathrm{O}$ molecules possessing the same energies. There is application of the method for mathematical models with different plants.

The distribution (\%, (- $\left.E_{\text {value }}\right) /\left(-E_{\text {total value }}\right)$ of $\mathrm{H}_{2} \mathrm{O}$ molecules in $1 \%$ of water extracts of fresh (green line) and dry $\mathrm{H}$. perforatum (red line) and dry $H$. perforatum with colloidal nano silver 30 ppm (brown line) as well as control sample deionized water (blue line) are shown of Fig. 1.

The results of the studies show a significant potential for stimulating effect of St. John's wort and espetially of the extracts of dried and fresh herb, on the nervous system of the body and to improve nerve conduction (the extre- 
Table 2. The spreading (\%, (- $\left.\mathrm{E}_{\mathrm{value}}\right) /\left(-\mathrm{E}_{\text {total value }}\right.$ ) of $\mathrm{H}_{2} \mathrm{O}$ molecules in water samples from fresh (green color) and dry $\mathrm{H}$. perforatum (red color) and dry $\mathrm{H}$. perforatum with colloidal nano silver $30 \mathrm{ppm}$ (brown color). The control sample is with blue color

\begin{tabular}{|c|c|c|c|c|c|c|c|c|c|}
\hline $\begin{array}{l}-E(e V) \\
x \text {-axis }\end{array}$ & $\begin{array}{c}\text { 1\% Water Solu- } \\
\text { tion of } \\
\text { Dry Hypericum } \\
\text { perforatum } \mathrm{L} . \\
\text { y-axis } \\
\left(\%\left(\left(-\mathrm{E}_{\text {value }}\right)^{\star} /\right.\right. \\
\left(-\mathrm{E}_{\text {total value }}\right)^{\star \star}\end{array}$ & $\begin{array}{c}1 \% \text { Water Solu- } \\
\text { tion of } \\
\text { Fresh Hypericum } \\
\text { perforatum } \mathrm{L} . \\
\text { y-axis } \\
\left(\%\left(\left(-\mathrm{E}_{\text {value }}\right)^{\star} /\right.\right. \\
\left(-\mathrm{E}_{\text {total value }}\right)^{\star \star}\end{array}$ & $\begin{array}{c}\text { 1\% Water Solu- } \\
\text { tion of } \\
\text { Dry Hypericum } \\
\text { perforatum L. } \\
\text { with } \\
\text { AgNP } 30 \text { ppm } \\
\text { y-axis } \\
\left(\%\left(\left(-E_{\text {value }}\right)^{\star} /\right.\right. \\
\left(-E_{\text {total value }}\right)^{\star \star}\end{array}$ & $\begin{array}{l}\text { Control Deion- } \\
\text { ized Water } \\
\left(\%\left(\left(-E_{\text {value }}\right)^{\star} \mid\right.\right. \\
\left(-E_{\text {total value }}\right)^{\star \star}\end{array}$ & $\begin{array}{l}-E(e V) \\
x \text {-axis }\end{array}$ & $\begin{array}{c}\text { 1\% Water Solu- } \\
\text { tion of } \\
\text { Dry Hypericum } \\
\text { perforatum L. } \\
\text { y-axis } \\
\left(\%\left(\left(-\mathrm{E}_{\text {value }}\right){ }^{\star} /\right.\right. \\
\left(-\mathrm{E}_{\text {total value }}\right)^{\star \star}\end{array}$ & $\begin{array}{c}1 \% \text { Water Solu- } \\
\text { tion of } \\
\text { Fresh Hypericum } \\
\text { perforatum } \mathrm{L} . \\
\text { y-axis } \\
\left(\%\left(\left(-\mathrm{E}_{\text {value }}\right)^{\star} /\right.\right. \\
\left(-\mathrm{E}_{\text {total value }}\right)^{\star \star}\end{array}$ & $\begin{array}{c}1 \% \text { Water Solu- } \\
\text { tion of } \\
\text { Dry } \\
\text { Hypericum per- } \\
\text { foratum } \mathrm{L} . \\
\text { y-axis } \\
\text { AgNP } 30 \text { ppm } \\
\left(\%\left(\left(-E_{\text {value }}\right)^{\star} /\right.\right. \\
\left(-E_{\text {total value }}\right)^{\star}\end{array}$ & $\begin{array}{c}\text { Control Deion- } \\
\text { ized Water } \\
\left(\%\left(\left(-E_{\text {value }}\right)^{\star} \mid\right.\right. \\
\left(-E_{\text {total value }){ }^{\star \star}}\right.\end{array}$ \\
\hline 0.0937 & 0 & 0 & 0 & 0 & 0.1187 & 0 & 8.2 & 4.3 & 15.8 \\
\hline 0.0962 & 0 & 0 & 0 & 10.5 & 0.1212 & $10.6^{2}$ & $16.4^{2}$ & $15.1^{2}$ & $0^{2}$ \\
\hline 0.0987 & 0 & 0 & 0 & 0 & 0.1237 & 0 & 0 & 0 & 5.3 \\
\hline 0.1012 & 10.5 & 0 & 4.3 & 0 & 0.1262 & 10.5 & 0 & 8.6 & 5.3 \\
\hline 0.1037 & 0 & 4.1 & 4.3 & 10.5 & 0.1287 & 0 & 8.2 & 6.7 & 0 \\
\hline 0.1062 & 0 & 4.1 & 0 & 0 & 0.1312 & 0 & 8.2 & 6.7 & 10.5 \\
\hline 0.1087 & 15.8 & 0 & 0 & 10.5 & 0.1337 & 15.8 & 13.1 & 8.6 & 5.3 \\
\hline 0.1112 & $15.8^{1}$ & $16.4^{1}$ & $11.1^{1}$ & $0^{1}$ & 0.1362 & 10.5 & 13.1 & 13.1 & 10.5 \\
\hline 0.1137 & 0 & 0 & 4.3 & 10.5 & 0.1387 & $10.5^{3}$ & $8.2^{3}$ & $8.6^{3}$ & $5.3^{3}$ \\
\hline 0.1162 & 0 & 0 & 4.3 & 0 & - & - & - & - & \\
\hline
\end{tabular}

For $(E=-0.1112 \mathrm{eV})(\lambda=11.15 \mu \mathrm{m})(\tilde{v}=897 \mathrm{~cm}-1)$ is the local extremum for stimulating effect on the nervous system and improving nerve conduction. For $(E=-0.1212 \mathrm{eV})(\lambda=10.23 \mu \mathrm{m})\left(\tilde{v}=978 \mathrm{~cm}^{-1}\right)$ is the local extremum for anti inflammatory activity.

For $(E=-0.1387 \mathrm{eV})(\lambda=8.95 \mu \mathrm{m})\left(\tilde{v}=1117 \mathrm{~cm}^{-1}\right)$ is the local extremum for suppressive effect on multiplication of neoplasm cells at the molecular level.

Notes:

${ }^{*}$ The $\left(-E_{\text {value }}\right)$ is the result of hydrogen bonds energy for one parameter of $(-E)$

${ }^{\star \star}$ The $\left(-E_{\text {total value }}\right)$ is the general result of hydrogen bonds energy

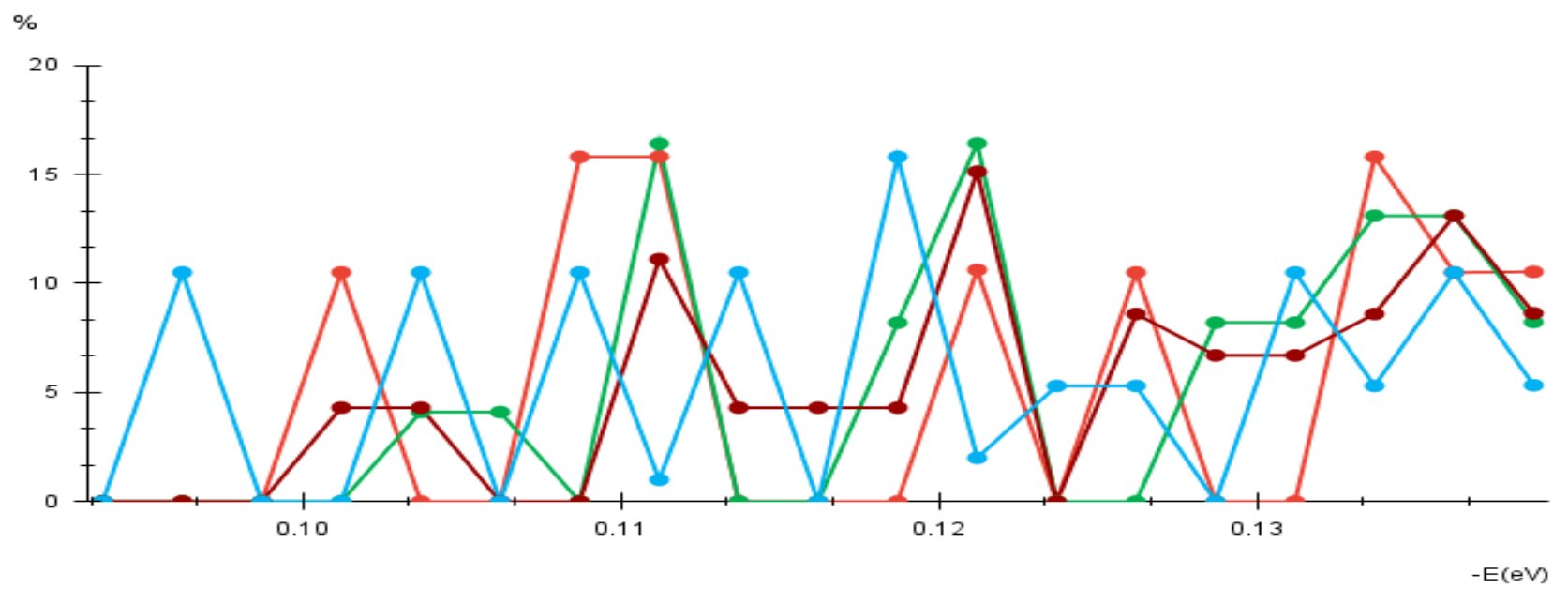

Fig. 1. Mathematical model, made by the method of Ignatov and Mosin (2013) of $1 \%$ water solutions of fresh (green color) and dry $H$. perforatum (red color), and dry H. perforatum with colloidal nano silver $30 \mathrm{ppm}$ (brown color). The control sample is with blue color.

\section{Notes:}

For $(E=-0.1112 \mathrm{eV})(\lambda=11.15 \mu \mathrm{m})\left(\tilde{\mathrm{v}}=897 \mathrm{~cm}^{-1}\right)$ is the local extremum for stimulating action on the nervous system and betterment of nerve conductivity.

For $(E=-0.1212 \mathrm{eV})(\lambda=10.23 \mu \mathrm{m})\left(\tilde{\mathrm{v}}=978 \mathrm{~cm}^{-1}\right)$ is the local extremum for anti-inflammatory activity.

For $(E=-0.1387 \mathrm{eV})(\lambda=8.95 \mu \mathrm{m})\left(\tilde{v}=1117 \mathrm{~cm}^{-1}\right)$ is the local extremum for suppression of development of neoplasm cells at the molecular level

mums at $\mathrm{E}=-0.1112 \mathrm{eV})$. The tested extracts, especially this vera (25), Justicia glauca (26), Arnebia nobilis (27), Alysicarfrom the fresh herb, as well as that from the dry one with pus monilifer (28), Lansium domesticum (29), Streptomyces the addition of nanosilver, have and anti-inflammatory ac- atrovirens (30), Cucumis sativus L. (31). Results show that tivity (determined at $\mathrm{E}=-0.1212 \mathrm{eV}$ ). The studied extracts colloidal nano silver with bio effects is released through have also the potential to inhibit the development of neo- green synthesis. The colloidal nano silver stimulates the plasm cells at the molecular level, especially that of the dry plant growth. Such researches were conducted using tomaherb (at $\mathrm{E}=-0.1387 \mathrm{eV}$ ).

In practice, colloidal silver is derived from medicinal plants with antioxidant, antimicrobial effects. Medicinal plants with such practical application are Catharanthus roseus (20), Aerva lanata (21), Indigofera aspalathoides (22), toes (32). The colloidal nano silver $30 \mathrm{ppm}$ of the Swiss company Evodrop that we added to dry H. perforatum extract in present research was studied and by other authors for biological effects (33-35).

The biochemical composition of the plants is mainly Croton bonplandianum (23), Azadirachta indica (24), Aloe determined by the soil and water. In our opinion, the re- 
sults obtained are in connection and with the content of stability of the stacked structure. Consequently, a two-layer biologically active substances in the studied herb. In multi-ring stacking pattern is energetically more favorable studies of Bulgarian St. John's wort (36) has been found than a single-ring four-layer stacking pattern. The correthat the total content of phenols as well as the antioxidant sponding structures for our results for water herbal extracts effect of the wild herb is higher than that of the cultivated of fresh $\mathrm{H}$. perforatum and of dry H. perforatum with AgNPs plant. The higher content of phenolic compounds in the $30 \mathrm{ppm}$ are shown in Fig. 2.

wild herb can be explained by differences in climatic conditions, the place of collection, as well as in the pretreatment processes.

It was reported that the maximum extraction of biologically active substances such as hyperforin, adhyperforin and 13, II8-biapigenin is obtained using fresh St. John's wort exposed to sunlight during maceration (37). Aqueous extracts of $H$. perforatum obtained with boiling water have a higher content of active components than those received at room temperature (38). Hypericin is known to be completely insoluble in water. Therefore, methods for overcoming this insolubility are being developed. Hyperforin is a lipophilic compound that decomposes rapidly upon exposure to heat or light (38). Other authors (39) tested the main compounds in an infusion of dried St. John's wort in deionized water at $95-100^{\circ} \mathrm{C}$ for $5 \mathrm{~min}$. They found that the infusion contained all bioactive components, although in lower concentrations, but lacked rutin and hyperforin. Hypericin and pseudohypericin are practically water insoluble at room temperature, but this can be overcome at higher temperatures. Therefore, St. John's wort infusion may contain almost half of the amount of these two compounds (8).

\section{Structuring of water clusters}

In $1 \%$ of water solutions of fresh and dry $H$. perforatum and dry $H$. perforatum with colloidal nano silver $30 \mathrm{ppm}$ and control sample deionized water.

In the tested extracts there are organic compounds of $H$. perforatum The number of water molecules for fresh $H$. perforatum was 16 molecules at $(-0.1212 \mathrm{eV})$. The number of water molecules for dry $H$. perforatum was 15 molecules at $(-0.1212 \mathrm{eV})$. For $(E=-0.1212 \mathrm{eV})(\lambda=10.23 \mu \mathrm{m})$ $\left(\tilde{v}=978 \mathrm{~cm}^{-1}\right.$ ) it is the local extremum showing antiinflammatory action (12). With these results we prove the high anti-inflammatory effect of the fresh and dried herb $H$. perforatum.

According to the model of Ignatov, Gluhchev, Neshev, Mehandjiev (12) the sizes of water clusters are: Dodeacader $\mathrm{D}_{4 \mathrm{~h}}$ with 16 and 15 water molecules.

The possible structure of clusters consisting of 15 and 16 water molecules could be supposed on the basis of the findings of (40) that asymmetric electron density of these molecules in a condensed phase makes possible only two hydrogen bonds per molecule on average. Thus, stable clusters of water molecules should be expected to have at least three hydrogen bonds per molecule. Along these lines, our results could be interpreted within the framework of a recent theoretical investigation of lowest-energy structures of water clusters consisting of arranged or single rings or multiple rings of tetramer, pentamer and hexamer (41). The authors have shown that, when single-ring stacking structures have more than 3 layers, the number of weak hydrogen bonds among the layers increases, thus reducing the

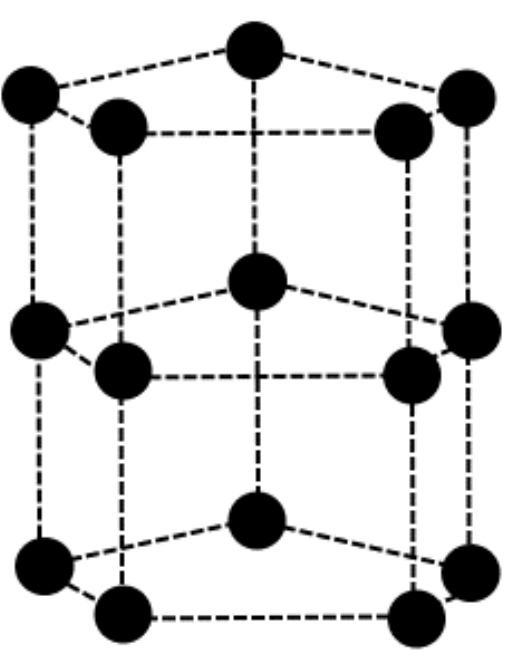

15 molecules

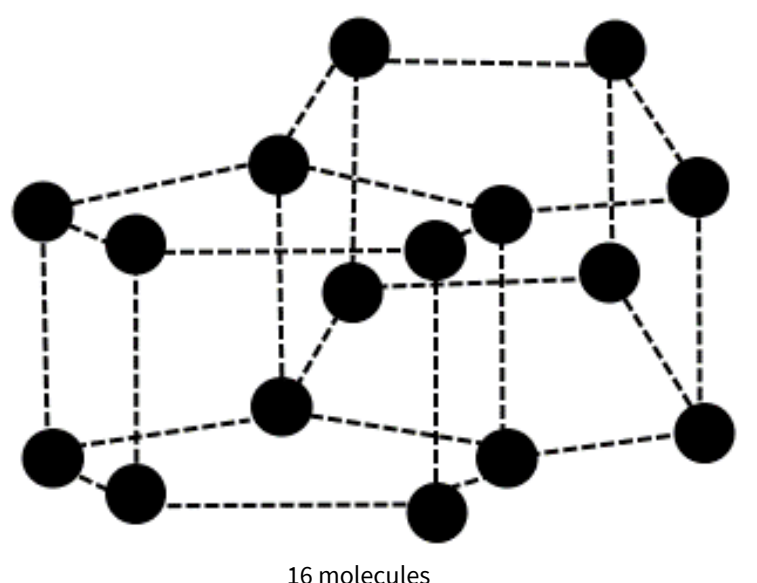

Fig. 2. Possible cluster structures in water herbal extracts of fresh $H$. perforatum and of dry H. perforatum with AgNPs $30 \mathrm{ppm}$.

Clusters of 16 and 15 water molecules are formed in these extracts. Here the circles depict the positions of the water molecules as a whole, without showing the exact directions of the hydrogen atoms and the dotted lines depict the hydrogen bonds.

\section{Conclusion}

For the first time, a spectral analysis of St. John's wort extracts was performed. In the current study of $H$. perforatum, AgNPs $30 \mathrm{ppm}$ was added to the dry herb. Comparative analysis was performed with fresh $\mathrm{H}$. perforatum The methods NES, DNES, mathematical models and a method for analysis of water clusters were applied.

The determined local extremums were in the zones showing stimulating action on the nervous system and betterment of nerve conduction $(E=-0.1112 \mathrm{eV})(\lambda=11.15 \mu \mathrm{m})$ $\left(\tilde{v}=897 \mathrm{~cm}^{-1}\right)$, also anti-inflammatory effect $(E=-0.1212 \mathrm{eV})$ $(\lambda=10.23 \mu \mathrm{m})\left(\tilde{v}=978 \mathrm{~cm}^{-1}\right)$ and inhibition of development of 
tumor cells at a molecular level $(E=-0.1387 \mathrm{eV})(\lambda=8.95 \mu \mathrm{m})$ $\left(\tilde{v}=1117 \mathrm{~cm}^{-1}\right)$.

The analysis revealed that in water herbal extracts of fresh $H$. perforatum and of dry H. perforatum with AgNPs 30 ppm are formed clusters of 16 and 15 water molecules.

The results of the fresh plant were better then these of the dry one. The effects of plant was increased with addition of colloidal nano silver (AgNPs).

\section{Compliance with ethical standards}

Conflict of interest: Authors do not have any conflict of interests to declare

Ethical issues: None.

\section{References}

1. Nestieva I, Valcheva-Kuzmanova S. Investigation of the variety and use of herbal antidepressants containing St. John's Wort (Hypericum perforatum) in Bulgaria for the period 2014-2016. Health Economics and Management. 2017;63(1):30-36 (in Bulgarian) https://doi.org/10.14748/hem.v63i1.4716

2. Staneva D, Panova D, Raynova L, Assenov I. Herbs in Every Home, Medicine and Physical Education, Sofia, 1982. p. 38-39 (in Bulgarian).

3. Belwal T, Devkota HP, Singh MK, Sharma R, Upadhayay S, Joshi C, Bisht K, Gour JK, Bhatt ID, Rawal RS, Pande V. St. John's Wort (Hypericum perforatum), Chapter 3.40, Nonvitamin and Nonmineral Nutritional Supplements, Elsevier. 2018. p. 415-32. https:// doi.org/10.1016/B978-0-12-812491-8.00056-4

4. EMEA. EMA/HMPC/244315/2016, Committee on Herbal Medicinal Products (HMPC), Assessment report on Hypericum perforatum L., herba, Draft Based on Article 10a of Directive 2001/83/EC as amended (well-established use). 30 Jan 2018.

5. Imreova P, Miadokova E, Galova E, Chankova S, Chalupa I. Potential anticlastogenic effect of hyperforin, Mil Med Sci Lett (Voj. Zdrav. Listy). 2013;82(4):180-84. https://doi.org/10.31482/ mmsl.2013.028

6. Milosevic T, Solujic S, Sukdolak S. In vitro study of ethanolic extract of Hypericum perforatum L. on growth and sporulation of some bacteria and fungi, Turk J Biol. 2007;31:237-41.

7. Karak P. Biological activities of flavonoids: an overview. Int J Pharm Sci Res. 2019;10(4):1567-74.

8. Patočka J. The chemistry, pharmacology and toxicology of the biologically active constituents of the herb Hypericum perforatum L. J Appl Biomed. 2003;1:61-70, https://doi.org/10.32725/ jab.2003.010

9. Klemow KM, Bartlow A, Crawford J, Kocher N, Shah J, Ritsick M. Medical Attributes of St. John's Wort (Hypericum perforatum), Chapter 11, In: Herbal Medicine: Biomolecular and Clinical Aspects, 2nd, ed. Publisher: Boca Raton (FL): CRC Press/Taylor \& Francis; Editors: Iris F. F. Benzie, Sissi Wachtel-Galor. 2011, https://doi.org/10.1201/b10787-12

10. Weber ND, Murray BK, North JA, Wood SG. The antiviral agent hypericin has in vitro activity against HSV-1 through non-specific association with viral and cellular membranes, Antivir Chem Chemother. 1994;5(2):83-90, https:// doi.org/10.1177/095632029400500204

11. Ignatov I, Mosin OV. Structural Mathematical Models Describing Water Clusters, Journal of Mathematical Theory and Modeling. 2013;3(11):72-87.

12. Ignatov I, Gluhchev G, Neshev N, Mehandjiev D. Structuring of water clusters depending on the energy of hydrogen bonds in electrochemically activated waters Anolyte and Catholyte. Bulg Chem Commun. 2021;53(2):234-39.

13. Antonov A. Research of the Non-equilibrium Processes in the Area in Allocated Systems. Dissertation thesis for PhD, Blagoevgrad, Sofia. 1995.

14. Antonov A, Yusskesseliva L, Teodossieva I. Influence of ions on the structure of water under conditions far away from equilibrium. Physiology. 1989;26(4):255-60.

15. Al-Shmgani HS, Mohammed WH, Sulaiman GM, Saadoon AH. Biosynthesis of silver nanoparticles from Catharanthus roseus leaf extract and assessing their antioxidant, antimicrobial, and wound-healing activities. Artif Cells Nanomed Biotechnol. 2017;45:1234-1240, doi.org/10.1080/21691401.2016.1220950

https://

16. Tododrov S, Damianova A, Sivriev I, Antonov A, Galabova T. Water energy spectrum method and investigation of the variations of the H-bond structure of natural waters. C R Acad Bulg Sci. 2008;61(7):857-62.

17. Appapalam ST, Panchamoorthy R. Aerva lanata mediated phytofabrication of silver nanoparticles and evaluation of their antibacterial activity against wound associated bacteria. J Taiwan Inst Chem Eng. 2017;78:539-51. https://doi.org/10.1016/ j.jtice.2017.06.035

18. Ignatov I, Popova T. Applications of Moringa oleifera Lam., Urtica dioica L., Malva sylvestris L. and Plantago major L. Containing potassium for recovery. Plant Cell Biotechnol Mol Biol J. 2021;22 (7-8):93-103.

19. Ignatov I, Popova T, Yaneva I, Balabanski V, Baiti S, Angelcheva M, Angushev I. Spectral analysis of Sambucus nigra L. fruits and flowers for elucidation of their analgesic, diuretic, antiinflammatory and anti-tumor effects. Plant Cell Biotechnol Mol Biol J. 2021;22(29-30):134-40.

20. Al-Shmgani HS, Mohammed WH, Sulaiman GM, Saadoon AH. Biosynthesis of silver nanoparticles from Catharanthus roseus leaf extract and assessing their antioxidant, antimicrobial and wound-healing activities. Artif Cells Nanomed Biotechnol. 2017;45:1234-40.

doi.org/10.1080/21691401.2016.1220950 https://

21. Appapalam ST, Panchamoorthy R. Aerva lanata mediated phytofabrication of silver nanoparticles and evaluation of their antibacterial activity against wound associated bacteria. J Taiwan Inst Chem Eng. 2017;78:539-51. https://doi.org/10.1016/ j.jtice.2017.06.035

22. Arunachalam KD, Annamalai SK, Arunachalam AM, Kennedy S. Green synthesis of crystalline silver nanoparticles using Indigofera aspalathoides medicinal plant extract for wound healing applications. Asian J Chem. 2013;25:311-14.

23. Beg M, Maji A, Mandal AK, Das S, Jha PK, Hossain M. Spectroscopic investigation on interaction of biogenic, Croton bonplandianum leaves extract mediated potential bactericidal silver nanoparticles with human hemoglobin and human serum albumin. J Biomol Struct Dyn. 2017;36:711-23. https:// doi.org/10.1080/07391102.2017.1294505

24. Bhagavathy S, Kancharla S. Wound healing and angiogenesis of silver nanoparticle from Azadirachta indica in diabetes induced mice. Int J Herb Med. 2016;4(5):24-29.

25. Chandran SP, Chaudhary M, Pasricha R, Ahmad A, Sastry M. Synthesis of gold nanotriangles and silver nanoparticles using Aloe vera plant extract. Biotechnol Prog. 2006;22:577-83. https:// doi.org/10.1021/bp0501423

26. Emmanuel R, Saravanan M, Ovais M, Padmavathy S, Shinwari ZK, Prakash P. Antimicrobial efficacy of drug blended biosynthesized colloidal gold nanoparticles from Justicia glauca against oral pathogens: a nanoantibiotic approach. Microb Pathog. 
2017;113:295-302, https://doi.org/10.1016/j.micpath.2017.10.055

27. Garg S, Chandra A, Mazumder A, Mazumder R. Green synthesis of silver nanoparticles using Arnebia nobilis root extract and wound healing potential of its hydrogel. Asian J Pharm. 2014;8:95-101, https://doi.org/10.4103/0973-8398.134925

28. Kasithevar M, Saravanan M, Prakash P, Kumar H, Ovais M, Barabadi H, Shinwari ZK. Green synthesis of silver nanoparticles using Alysicarpus monilifer leaf extract and its antibacterial activity against MRSA and CoNS isolates in HIV patients. J Interdiscip Nanomed. 2017;2:131-41. https://doi.org/10.1002/jin2.26

29. Shankar S, Jaiswal L, Aparna RSL, Prasad RGSV, Kumar GP, Manohara CM. Wound healing potential of green synthesized silver nanoparticles prepared from Lansium domesticum fruit peel extract. Mater Express. 2015;5:159-64. https://doi.org/10.1166/ mex.2015.1225

30. Subbaiya R, Saravanan M, Priya AR, Shankar KR, Selvam M, Ovais $M$, Balajee R, Barabadi H. Biomimetic synthesis of silver nanoparticles from Streptomyces atrovirens and their potential anticancer activity against human breast cancer cells. IET Nanobiotechnol. 2017;11:965-72. https://doi.org/10.1049/ietnbt.2016.0222

31. Venkatachalam P, Sangeetha P, Geetha N, Sahi SV. Phytofabrication of bioactive molecules encapsulated metallic silver nanoparticles from Cucumis sativus L. and its enhanced wound healing potential in rat model. J Nanomater. 2015;16:241-49. https:// doi.org/10.1155/2015/753193

32. Zakharova OV. Sodium tallow amphopolycarboxyglycinatestabilized silver nanoparticles suppress early and late blight of Solanum lycopersicum and stimulate the growth of tomato plants. Bio Nano Science. 2017;7, 692-702, https:// doi.org/10.1007/s12668-017-0406-2

33. Popova T, Ignatov I. In vitro Antimicrobial activity of colloidal nano silver. Bulg J Vet Med. 2021. Online First. Available from: http://tru.uni-sz.bg/bjvm/2411\%20Popova\%20\&\%20lgnatov\% 200nFirst.pdf
34. Valcheva N, Ignatov I, Huether F. Microbiological research of the effects of EVODROP silver nanoparticle on Escherichia coli, Enterococci and Coliforms. Journal of Advances in Microbiology. 2020;20(11):22-31. https://doi.org/10.9734/jamb/2020/ v20i1130297

35. Popova, T. P., I. Ignatov, F. Huether, T. Petrova. Antimicrobial activity of colloidal nanosilver $24 \mathrm{ppm}$ in vitro Bulgarian Chemical Communications, 53, 3, 365 - 70, 2021. DOI: 10.34049/ bcc.53.3.5404.

36. Chimshirova R, Karsheva M, Diankov S, Hinkov I. Extraction of valuable compounds from bulgarian St. John's wort (Hypericum perforatum L.) antioxidant capacity and total polyphenolic content. J Chem Technol Metall. 2019;54(5):952-61.

37. Isacchi B, Bergonzi MC, Carnevali F, van der Esch SA, Vincieri FF, Bilia AR. Analysis and stability of the constituents of St. John's wort oils prepared with different methods. J Pharm Biomed Anal. 2007; 45:756-61. https://doi.org/10.1016/j.jpba.2007.08.025

38. Franchi GG, Nencini C, Collavoli E, Massarelli P. Composition and antioxidant activity in vitro of different St. John's Wort (Hypericum perforatum L.) extracts. J Med Plant Res. 2011;5 (17):4349-53.

39. Zeliou K, Kontaxis NI, Margianni E, Petrou C, Lamari FN. Optimized and validated HPLC analysis of St. John's Wort extract and final products by simultaneous determination of major ingredients. J Chromatogr Sci. 2017;55(8): 805-12. https:// doi.org/10.1093/chromsci/bmx040

40. Wernet $P$, Nordlund D, Bergmann U, Cavalleri M, Odelius M, Ogasawara H, Näslund LA, Hirsch TK, Ojamäe L, Glatzel P, Pettersson LG, Nilsson A. The structure of the first coordination shell in liquid water. Science. 2004;304:995-99. https:// doi.org/10.1126/science.1096205

41. Yang L, Ji H, Liu X, Lu WC. Ring-stacking water clusters: Morphology and Stabilities. ChemistryOpen. 2019;8(2):210-18. https:// doi.org/10.1002/open.201800284 